\title{
前立腺がん検診の費用効果分析
}

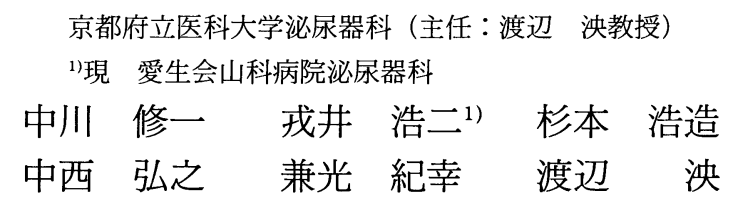

\section{COST-EFFECTIVENESS ANALYSIS OF PROSTATIC CANCER SCREENING}

\author{
Shuichi Nakagawa, Koji Ebisui, Kozo Sugimoto, Hiroyuki Nakanishi, \\ Noriyuki Kanemitsu and Hiroki Watanabe \\ Department of Urology, Kyoto Prefectural University of Medicine \\ (Director: Prof. H. Watanabe)
}

(Background) To evaluate how much mass screening for prostatic cancer (PC) would benefit the nation economically, cost-effectiveness of PC screening was analyzed.

(Methods) The cost per life-year saved (cost-effectiveness ratio; CER) was compared between PC screening and other 5 already established cancer screenings in Japan by an analytical simulation model to estimate cost and effectivenss of various screening programs, which was proposed recently by Hisamichi and Kamae.

(Results) Although CER in PC screening amounted $204 \times 10^{3}$ yen for males aged from 55 to 59 years of age, among males more than 60 years of age, CER became negative, which meant a positive balance might be obtained economically by the adoption of screening. CER of PC screening was similar to that of colorectal cancer screening, while was 2 to 14 times lower than that of the remaining 4 established cancer screenings. According to the sensitivity analysis, the rate of the prevalence of $\mathrm{PC}$, as well as the rate of the examinees for the secondary study influenced remarkedly the cost-effectiveness of PC screening.

(Conclusion) The morbidity and mortality of PC has seriously increased in the past years in Japan and the number of PC patients in 2015 is anticipated to show a 5.19 -fold increase of that in 1990. According to such considerable increase of PC patients in the near future, PC screening is thought to be an economically well-balanced public activity.

Key words: prostatic cancer, mass screening, cost-effectiveness analysis

要旨：(背景と目的)前立腺がん検診を国家レベルで実施すると，国にとっていかに経済的な利益がある かを検討するため, その費用効果分析を行い, 各種がん検診のそれと比較した.

（方法）今回用いた久道一鎌江のモデルは，ある年齢階級の無症状の仮想コホートを 10 万人設定し, 前立腺がん検診を 1 回のみ実施した場合（検診群）と，検診を全く行わず自覚症状によって医療機関を 受診した場合（非検診群）の費用と効果を, 有病率, 検診精度, 5 年生存率, 平均余命, 検診・診断・ 治療費より推定するものである. 費用・効果ともに，両群間の差を求め， 1 期待生存年数あたりの費用 （費用効果比）を計算した.

（結果）前立腺がんの費用効果比は55～59歳で204千円であったが，60歳以上では非検診群の費用が検 診群の費用を上回り，検診を行うことにより国家全体に経済的利益をもたらすと試算された。この成績 は大腸がん検診とほぼ同程度であり, 他のがん検診（胃・子宮・乳房・肺）と比べれば格段に費用効果 が良かった.さらに有病率について感度分析を行ってみると, 前立腺がんは我が国で現在最も増加して いるがんであるが，1990年の有病率によって計算しても，その費用効果比は乳がん検診や女子の肺がん 
検診の費用効果比より良好であり，今後その差は拡がるものと予想された.

（結論）以上のごとく前立腺がん検診は，様々な条件において既設の他のがん検診と比較してみても， より経済的効率の高いがん検診であると考えられた。 キーワード：前立腺がん, 集団検診, 費用効果分析

\section{緒 言}

現在我が国では老人保健法に基づくがん検診とし て，胃がん・子宮がん・乳がん・肺がん・大腸がんの 検診が行われている. 前立腺がんについても, 老人保 健事業への導入の可否を検討するために，1994年から 厚生省がん研究助成金「前立腺がんの集団検診の妥当 性に関する研究」渡邊班がスタートした。がん検診の 導入にあたっては，その有効性のみならず，経済性・ 安全性・普及性などが検討されなければならない ${ }^{11}$.し かし，これまで我が国における前立腺がん検診の経済 性についての報告2゙は少ない。

一方，1995年11月に東京で開催された「がん検診と 経済評価に関する会議」(厚生省がん研究助成金「各種 がん検診の共通問題に関する研究」久道班主催）にお いて「保健事業における社会経済的評価法の標準ガイ ドライン」 ${ }^{3)}$ が作成されたことにより, 各がん検診の経 済性に関して，一定の基準の下で討議することが可能 となった。

今回, 本ガイドラインを用いて前立腺がん検診の費 用効果分析を行い，他のがん検診との比較検討を行っ た。さらに費用効果に影響を及ぼすと考えられている 有病率・精密検查受診率・治療費・スクリーニング検 査の感度・特異度について感度分析を行い, その変動 を検討した。

\section{対象と方法}

本ガイドラインでは, ある年齢階級の無症状の仮想 コホート（検診群）を 10 万人設定し, 前立腺がん検診 を 1 回のみ実施した場合の費用と効果を推定してい る. 前立腺がんの有病率, 検診の感度 - 特異度, 5 年 生存率より進行度別の発見がん患者数を算出し, 5 年 生存率と平均余命より患者の生存年数を計算する. 費 用は検診・診断・治療費に分けて計算する. 効果の指 標は救命患者数および救命年数とする，同様に検診を 全く行わないコホート (非検診群) を設定し, 前立腺 がん患者全員が自覚症状によって医療機関を受診した と仮定して, 費用と効果を計算する. 費用・効果とも に, 検診群と非検診群の差（限界費用・限界効果）を 分析の指標とする。限界費用を限界効果で除した值を もって, 救命 1 人あたりの費用および 1 期待生存年数
あたりの費用（費用効果比）とする.

前立腺がん検診のスクリーニング検査は，経直腸的 超音波断層法 (TRS), 直腸内指診 (DRE), 前立腺特 異抗原（PSA）の 3 者があるが，ここでは渡邊班が国 家レベル検診として提唱している PSA をスクリーニ ング検查に用いた前立腺がん検診システム4)5)をもと に費用効果を算出した。

今回の費用効果分析に用いる数值を表 1 に示した. すなわち，(1)有病率は，検診の発見率に偽陰性例（検 診での見逃し）を加えたものである．つまり，前立腺 検診協議会で集計した年代別前立腺がん発見率6)感 度で除した值を有病率とした。なお，発見率の根拠と した集団検診の約 $95 \%$ はスクリーニング検査に PSA を用いている ${ }^{6}$. (2)感度・特異度は, 前立腺生検に systematic biopsy を用いた検診で PSA のカットオフ値 を $4.3 \mathrm{ng} / \mathrm{ml}$ (耳血 PSA 法では $3.0 \mathrm{ng} / \mathrm{ml}$ に相当) とし た場合の感度・特異度とした ${ }^{7)}$ 。なお, 感度・特異度は 全年齢階級で同じと仮定した。(3)外来発見がん（非検 診群）と検診発見がん（検診群）の 5 年生存率は, 両 群間に年齢差を認めたため相対生存率を用いた。なお, 相対生存率は全年齢階級で同じと仮定した。(4)検診費 用については，スクリーニング検査の費用を，保険診

表 1 費用効果分析に用いる数值とその根拠

(1) 前立腺がんの有病率 $\left(=\right.$ 前立腺がんの発見率 $\left.{ }^{6}\right) \div$ 感度 $\left.{ }^{7}\right)$ (\%)

55〜 59歳：0.192，60～69歳：0.479，70～79歳：1.464

(2) スクリーニング検査(PSA)

感度 ${ }^{7)}: 0.875$, 特異度 ${ }^{7)}: 0.967$

(3) 5 年生存率 (相対生存率：全年齢階級同じと仮定)

非検診群: 0.659 , 検診群 : 0.830

(4) 検診費用 ${ }^{8)}: 1,580$ 円

(5) 診断費用 (表 2 参照) 非検診群：28,500円，検診群：20,850円

(6) 治療費 ${ }^{10)}$

救命群：200万円, 死亡群：600万円

(7) 精密検査受診率: $100 \%$, 精密検査の感度・特異度 : $100 \%$ と仮定

(8) 救命群の平均生存年数 ${ }^{11}$

55 59歳：22.88年, $60 \sim 69$ 歳：16.67年,

$70 \sim 79$ 歳: 9.96 年

(9) 死亡群の平均生存年数 ${ }^{12)}: 3$ 年 
表 2 前立腺がんの診断費用

(平成 8 年度「社会保険 - 老人保健診断報酬医科点数表の解 釈」9)による)
(1) 初診料
(2) 経直腸的超音波検査
（超音波穿刺術を含む）
(3) 前立腺針生検法
(4) 病理組織顕微鏡検查
(5) 病理学的検査判断料
(6) 薬剤投与
（ケフラール 6 錠を 3 日間に調材料，処方料，調剤技術基本 料, 薬剤情報提供加算料を含む)
(7) PA 精密測定
$\cdots 2,750$ 円

ただし「病理医のいる病院」の診断費用, * ${ }^{*}$ 「医院・診療

所」, ** : 「病理医のいない病院」

療点数ではなく，1,000例を一括測定した場合の PSA 測定の費用に，事務・人件費を加えた 1,580 円 $^{8)}$ とした。 (5)診断費用は，検診の精密検査も医療機関において保 険診療で行うため，検診群・非検診群ともに「社会保 険・老人保健診療報酬医科点数表の解釈 (平成 8 年 4 月版) $\rfloor^{9}$ に従い計算した。病院と診療所で若干の違い はあるが(表 2 )，その平均をとって非検診群は 28,500 円（表 2 の(1)〜 (7)の合計）とした。検診群の診断費用 はスクリーニング検査の結果により異なる。すなわち PSA が $10.1 \mathrm{ng} / \mathrm{ml}$ 以上 (陽性：全受診者の $2.0 \%{ }^{5)}$ ) で は，TRS と DREを行った上で必ず前立腺生検を行 い, (1)〜6)の費用がかかる. PSA が4.1〜10.0ng/ml (グレーゾーン：全受診者の5.1\%年) ではTRS と DRE を行い，いずれかでがんが疑われた $63 \%{ }^{5)} に$ 生検 を行い, 表 2 の(1)（6)費用がかかる．残りの37\%は 生検を行わないので, 表 2 の(1)(2)の費用ですむ. 以上 を平均すると 20,850 円であった，6治療費は，京都府 立医科大学附属病院での実際の治療費を算出して，救 命群が 200 万円, 死亡群が 600 万円とした ${ }^{10)}$. (7)精密検査 受診率は $100 \%$ ，精密検査の感度・特異度はそれぞれ $100 \%$ と仮定した. 8)救命群の平均生存年数は, 平成 6 年の簡易生命表 ${ }^{11)}$ を用いて, 各年齢階級の中間值の平 均余命とした。(9)死亡群の平均生存年数は, 臨床病期 D の $50 \%$ 生存期間である 3 年とした ${ }^{12)}$.

費用効果比に影響を及ぼすと考えられる有病率・精 密検査受診率・治療費・スクリーニング検査の感度・ 特異度の 5 項目について感度分析を行った。まず有病 率であるが，本ガイドライン光では各がんの有病率は がん検診での発見率を感度で補正したものを用いた。 老人保健法で行われている各がん検診は, 年間数百万
人の受診者があるのに対して，前立腺がん検診では年 間 1 万人程度 ${ }^{6}$ に過ぎず，今後大規模に行われた場合 にはがん発見率が変わることもある。そこで有病率に ついては, 現在值とその 0.1 倍まで低下させて感度分析 を行った。精密検査受診率については, 各種がん検診 との比較のために $100 \%$ と仮定して計算した.しかし現 実には，集団検診の規模が大きくなるほど低下する傾 向にあり, 精密検査受診率の低下は偽陰性例の増加に つながる，そこで現実的な精密検査受診率である $40 \%$ から $100 \%$ まで変動させて感度分析を行った。治療法は 複数の選択肢があり ${ }^{1314)}$ ，それによって治療費も異な る.さらに症例ごとに治療内容も異なることから, 治 療費については，ある程度の幅をもつて予測する必要 がある. 救命群の 200 万円は, 京都府立医科大学附属病 院で前立腺全摘除術を行った場合の費用 ${ }^{10)}$ であるが, ホルモン療法としての除睾術だけを行った場合には50 万円，また LH-RH アナログを用いた場合には400万円 となる.そこで, 救命群は50万円から400万円までの範 囲で感度分析を行った。一方, 死亡群の600万円はホル モン療法・化学療法・放射線療法などを行った場合の 治療費である ${ }^{10)}$. しかし近年, がんの告知や在宅ホスピ スの拡がりに伴い, 終末期を自宅で過ごす人も増えて いる．このような場合には治療費用は $2 / 3$ 程度の 400 万 円となる、また逆に, 安全に化学療法が行えるように なったことから, 化学療法を施行する症例も増えてお $\eta^{15)}$, その場合の治療費は1.5倍程度の 900 万円となる. そこで, 死亡群は400万円から900万円までの範囲で感 度分析を行った。 スクリーニング検査の感度・特異度 については，(1)報告者により異なる，(2)より鋭敏な PSA 測定キットが展開されつつある. (3)しかし感度・ 特異度が低すぎては検診として成り立たない, ことを 考慮して各々 70〜 100\%の範囲で感度分析を行った。

\section{結 果}

1. 本ガイドラインを用いた計算例

本ガイドラインを用いて計算した前立腺がん検診 （60～69歳, 精密検查受診率70\%)の具体例を図 1 に示 した。すなわち, 非検診群のがん患者数は, 有病率

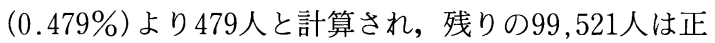
常者である. がん患者は, 外来発見がんの 5 年生存率 により 316 人 $(65.9 \%)$ が救命され，163人 $(34.1 \%)$ が死亡する, 一方, 検診群では, スクリーニング検査 異常なしのうち正常者は，99,521人に特異度（0.967） を掛けた 96,237 人, 要精密検査のうち正常者は, 99,521 人から 96,237 人を引いた 3,284 人となる.一方, 要精密 
図 1 前立腺がん検診に関する判断樹

(例：60～69歳，精密検査受診率70\%)

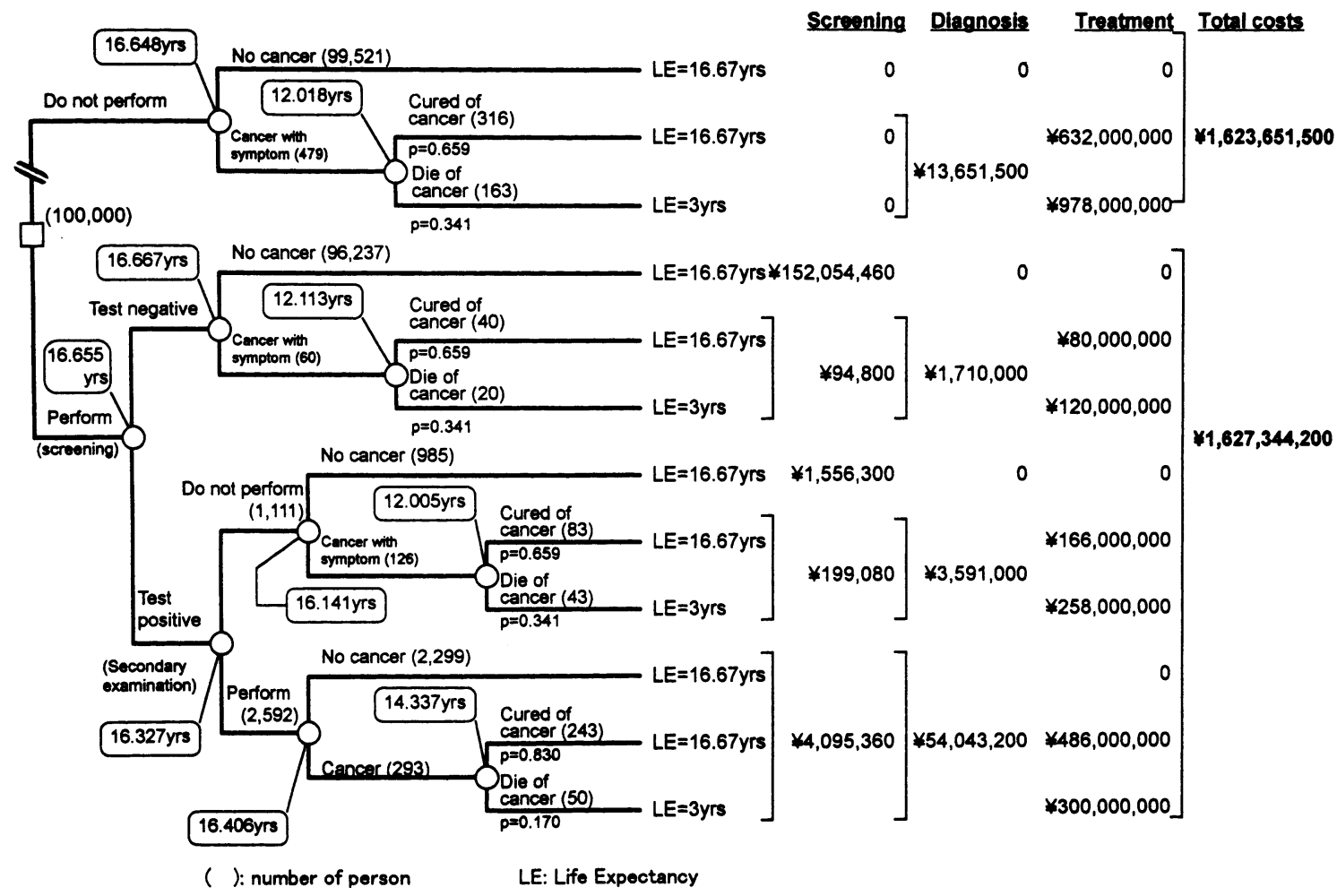

検査のうちがん患者は 479 人に感度（0.875）を掛けた 419 人，スクリーニング検査異常なしのがん患者は 479 人から 419 人を引いた 60 人となる.精密検査受診者と末 受診者のがんの比率が同じで，スクリーニング検査異 常なしと精密検查未受診のがん患者は, 非検診群と同 じ比率で救命, 死亡する。検診発見がんは, その 5 年 生存率により 243 人 $(83.0 \%)$ が救命され, 50 人 $(17.0 \%)$ が死亡する。

2. 費用と効果の比較

前立腺がん検診の対象年齢は，50歳以上 ${ }^{16)}$ あるいは 55歳以上 ${ }^{10)}$ といまだ議論のあるところである. 本論文 では渡邊班の合意事項となっている55歳以上 ${ }^{8)}$ とし た.そこで表 1 の数值を代入して，55～59歳， 60～69 歳 (60歳台), 70〜 79歳（70歳台）の年齢階級別の 1 人 あたりの費用と限界費用を表 3 に示した。 55～59歳で は1,134円であったが, 60, 70歳台ではマイナスとなっ た.マイナスとは，検診を行わなかった場合の総費用 が行った場合の総費用を上回ったわけで，検診を行え ば行うほど国家全体でみると経済的に利益が出ること を示す. 60,70 歳台と年歯が上昇するにつれてその額
表 3 限界費用

\begin{tabular}{c|c|c|c}
\hline \multirow{2}{*}{ 年齢 } & \multicolumn{3}{|c}{ 費用 ( 1 人あたり) (円) } \\
\cline { 2 - 4 } & 検 診 群 & 非検診群 & 差(限界費用) \\
\hline $55-59$ & 7,629 & 6,495 & 1,134 \\
$60-69$ & 15,589 & 16,237 & -648 \\
$70-79$ & 43,057 & 49,657 & $-6,600$ \\
\hline
\end{tabular}

も大きくなった.

救命患者数と期待生存年数の限界効果を表 4 に示し た.人口 10 万人あたりの救命患者数は年齢が上昇する につれ 28 人から 219 人に増加した. 期待生存年数も年齢 が上昇するにつれ556年から 1,524 年に増加した。

3. 費用効果比

以上の結果より，救命 1 人あたりの費用と， 1 期待 生存年数あたりの費用 (費用効果比) を表 5 に示した. 救命 1 人あたりの費用は55〜59歳では4,050千円で あったが，60歳台以上ではマイナスで，救命するたび に利益が出る計算となった。費用効果比は55〜 59歳で 204千円であったが, 60歳台以上では同じくマイナスで あった。 
表 4 限界効果（人口 10 万人あたり）

\begin{tabular}{c|c|c|c|c|c|c}
\hline \multirow{2}{*}{ 年齢 } & \multicolumn{3}{|c|}{ 救命患者数 (人) } & \multicolumn{3}{|c}{ 期待生存年数 (年) } \\
\cline { 2 - 7 } & 検 診 群 & 非検診群 & $\begin{array}{c}\text { 差 } \\
\text { (限界効果) }\end{array}$ & 検 診 群 & 非検診群 & $\begin{array}{c}\text { 差 } \\
\text { (限界効果) }\end{array}$ \\
\hline $55-59$ & 155 & 127 & 28 & $2,287,264$ & $2,286,708$ & 556 \\
$60-69$ & 388 & 316 & 72 & $1,665,756$ & $1,664,772$ & 984 \\
$70-79$ & 1,184 & 956 & 219 & 994,051 & 992,527 & 1,524 \\
\hline
\end{tabular}

表 5 救命 1 人あたりと 1 期待生存年数あたりの費用 (千円)

\begin{tabular}{c|c|c}
\hline 年齢 & 救命 1 人あたり & $\begin{array}{c}1 \text { 期待生存年数あたり } \\
\text { (費用効果比) }\end{array}$ \\
\hline $55-59$ & 4,050 & 204 \\
$60-69$ & -899 & -65 \\
$70-79$ & $-3,013$ & -433 \\
\hline
\end{tabular}

図 2 有病率の変化に伴う費用効果比の変動

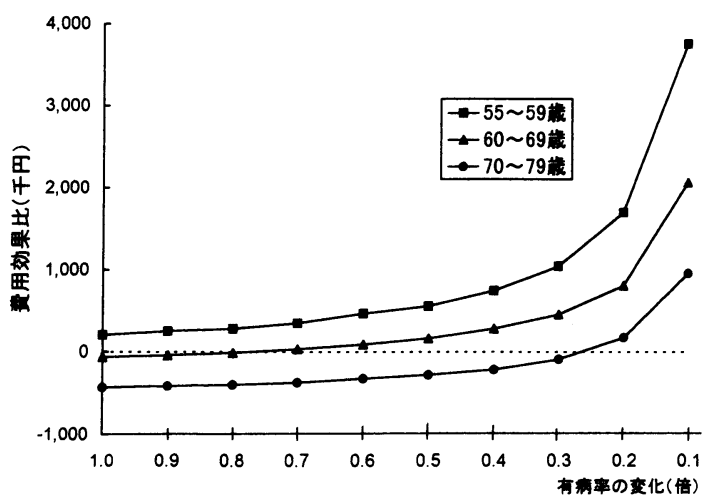

\section{4. 感度分析 \\ (1) 有病率}

有病率が現在の 0.4 倍程度までは, 最も費用効果比が 高い55～59歳でも750千円を越えなかったが, それ以下 になると急激に上昇した。60歳台では 0.3 倍程度までは 500 千円を越えず, 70 歳台では 0.2 倍程度までは 200 千円 を越えなかったが，それ以下では同じく急激に上昇し た（図 2 ).

\section{(2) 精密検査受診率}

若い年代ほど受診率による費用効果比の差が大き かった. 費用効果比が最も高い55～59歳では，受診率 が100\%から40\%に低下すると 3 倍となった（図 3 ）。

\section{(3) 治療費}

救命群の治療費が上昇するにつれ費用効果比も上昇 したが，55〜59歳では治療費が 8 倍になってもその上
図 3 精密検査受診率の変化に伴う費用効果比の変動

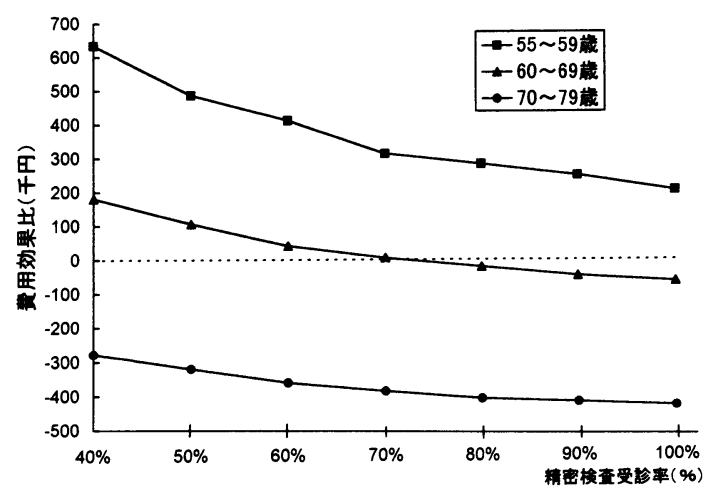

図 4 救命群の治療費の変化に伴う費用効果比の変動

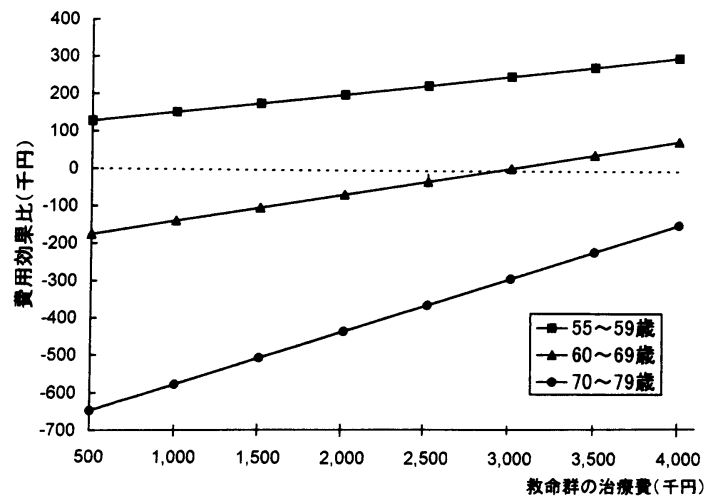

昇は180千円程度であった（図 4). 逆に, 死亡群の治 療費用が上昇するにつれ費用効果比は低下したが，そ の差は250千円程度であった。いずれにせよ, 治療費の 変動は有病率や精密検查受診率の変動と比較して費用 効果比に及ぼす影響は小さかった（図 5 )。

(4) スクリーニング検査の感度・特異度

感度が低下するにつれ費用効果比は上昇したが，そ の変動は小さかった(図 6 )。一方, 特異度は低下する につれて，急激に費用効果比が上昇した（図 7 ）。 
図 5 死亡群の治療費の変化に伴う費用効果比の変動

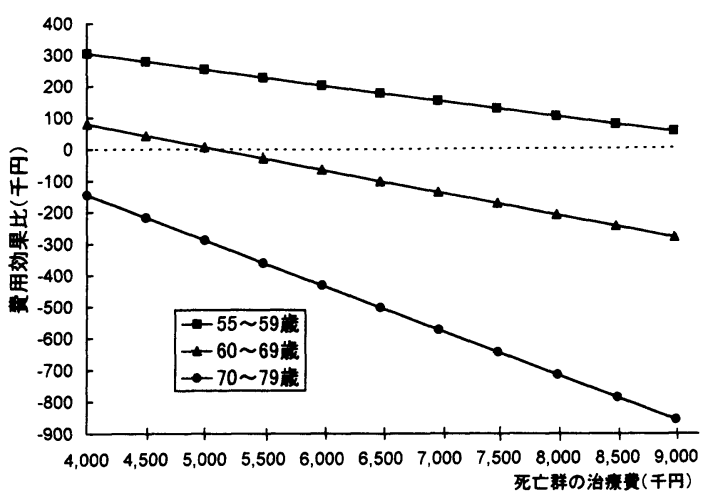

図 6 スクリーニング検査の感度の変化に伴う費用効 果比の変動

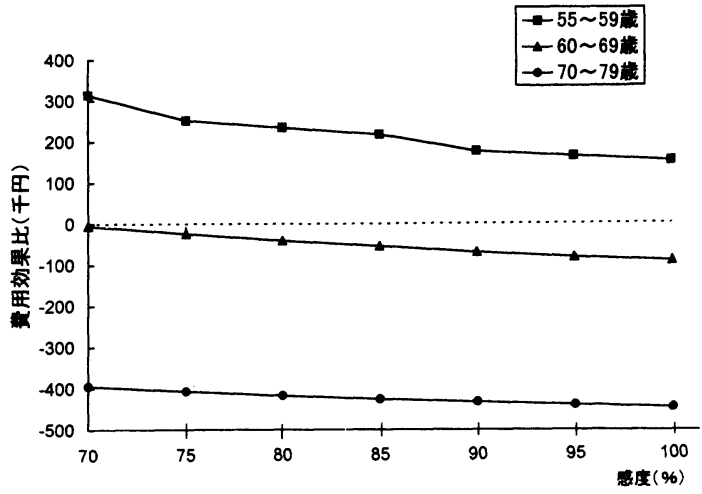

図 7 スクリーニング検査の特異度の変化に伴う費用 効果比の変動

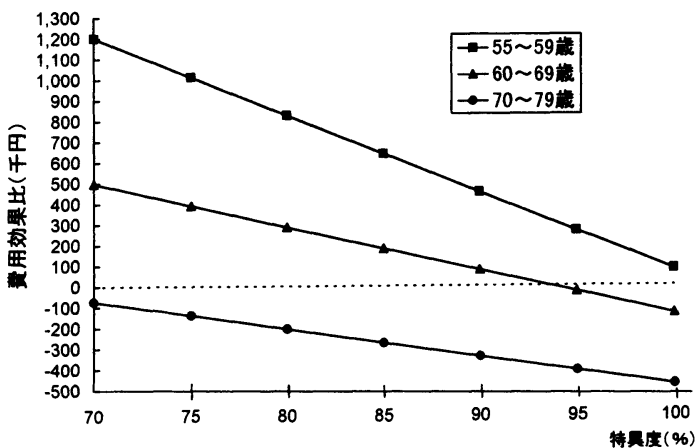

\section{考察}

我が国の前立腺がん罹患率・死亡率の増加は著しく， その対策として, 前立腺がん検診の老人保健事業への 導入が検討されている．前立腺がん検診を国家事業で
行う場合には，有効性のみならず経済性も検討されな ければならない ${ }^{11}$ 。保険医療の経済的評価法とは，費 用・結果の両面から見た行動選択肢の比較分析である. これは限りある費用を用いて，より良い結果をもたら す複数の案を比較検討することである ${ }^{17)}$. したがって, 1）複数の代替案を比較している，2）代替案の費用と 結果をもとに検討している，の 2 項目を満たさなけれ ばならない ${ }^{17)}$ 。この条件を満たした本ガイドライン ${ }^{33}$ による各がんの費用効果比 ${ }^{12}$ （表 6 ）の比較検討から は, 前立腺がんの費用効果比は大腸がんとならび格段 に良かった。

これまで我が国における前立腺がん検診の経済的効 果を検討した報告は, 中尾らのもの兇しかない.これに よると,TRS をスクリーニング検査に用いた前立腺集 団検診を 2 年に 1 回, 55 歳以上の男子全員が受診すれ ば，理論的には我が国から前立腺がんを撲滅させるこ とが可能で，しかも前立腺がん撲滅費の推計額は前立 腺がん治療費の推計額より年間約60億円少額となると いう. 今回の検討は，これとはまったく異なる方法論 によったものだが，やはり似たような結果が出た。一 方，すでに老人保健事業として施行されている胃がん 検診における費用効果分析では，検診によって救命さ れたことによる「生命の值段」を含めないと黒字にな らない ${ }^{19}$ ので，前立腺がん検診に比べるとかなり費用 効果が悪い。

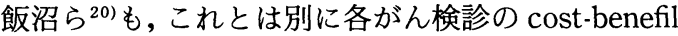
を計算する簡易モデルを提案している. 今回の検討と はモデルが異なるため, 費用効果比の数值そのものを 比較することはできないが, 各モデル内での比較は可 能であり，それによっても前立腺がんの検診は相当な positive benefit が見込める ${ }^{10)}$.

このように前立腺がん検診の経済効率がよい理由と しては, 罹患者の $99 \%$ が高齢男子に限られていること, よいスクリーニング検查法があること，早期がんは治 療させうること，などが挙げられよう.

しかし前述のごとく，前立腺がん検診の受診者は年 間 1 万人程度であるため, 発見率から求めた有病率が 真の值とはいえない.そこで有病率の変化が費用効果 比にどのような影響を与えるかを知るため, 感度分析 を行った。1990年の前立腺の粗罹患率・粗有病率は人 口10万対でそれぞれ $12.8^{21)}, 47.0^{22)}$ である.年齢階級別 の粗有病率は不明であるが，年齢階級別粗罹患率は

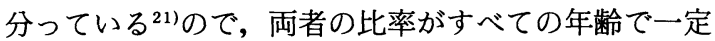
であるならば，55～59歳，60，70歳台の有病率はそれ 
表 6 各種がん検診の費用効果比の比較（千円）

\begin{tabular}{c|c|c|c|c|c|c|c|c|c}
\hline \multirow{2}{*}{ 年齢 } & \multirow{2}{*}{ 前立腺がん } & \multicolumn{2}{|c|}{ 胃 } & \multirow{2}{*}{ が } & \multirow{2}{*}{ 子宮がん } & 乳 がん & \multicolumn{2}{|c|}{ 肺 が } & \multicolumn{2}{|c}{ 大腸がん } \\
\cline { 6 - 9 } & & (男) & (女) & & & (男) & (女) & (男) & (女) \\
\hline $30-39$ & - & - & - & 334 & 3,094 & - & - & - & - \\
$40-49$ & - & 1,253 & 1,007 & 709 & 1,760 & $5,050 / 5,090$ & $6,980 / 4,280$ & 252 & 349 \\
$50-59$ & $204^{* *}$ & 564 & 1,016 & 894 & 2,986 & $1,820 / 779$ & $3,700 / 3,050$ & 59 & 197 \\
$60-69$ & -65 & 147 & 707 & 1,047 & 2,460 & $623 / 446$ & $2,110 / 2,140$ & -39 & 136 \\
$70-79$ & -433 & 135 & 696 & 1,784 & 3,889 & $167 / 127$ & $2,170 / 1,600$ & -10 & 132 \\
\hline
\end{tabular}

*：5 歳間隔の費用効果比 (例：40-44歳/45-49歳), ${ }^{* *}: 55 \sim 59$ 歳

ぞれ0.022，0.118，0.455となる. その費用効果比(表 7 ) は, 最も高い55～59歳で2,649千円となるが, これ でもすでに老人保健事業に採用されている乳がん検診 や女子の肺がん検診の費用効果比 (表 6 ) よりも安い. しかも, 我が国における前立腺がんの罹患率の増加比 はすべてのがんの中で最も高く ${ }^{23)}, 2015$ 年になれば現 在の5.19倍に増加すると予想されるので ${ }^{23)}, 2015$ 年の 55～59歳の費用効果比は1,439千円と減少し（表 7 )， 今後罹患率の減少が予想されている ${ }^{23)}$ 胃がんや子宮が んの費用効果比と比べても，十分に太刀打ちできると ころまで差が縮まると考えられる。

感度分析の結果, 精密検査受診率が費用効果比に大 きく影響することもわかった。私たちが国家レベル検 診として提唱している基本健康診査に相乗りした前立 腺がん検診システム ${ }^{5)}$ では, 精密検査受診率は $88.2 \%$ と高いので，それに基づき計算すると，55〜 59歳では 236千円 (表 7 ) となる。一方, Imai らが大規模に行っ ている前立腺がん検診の精密検査受診率 $44.8 \%{ }^{24)}$ では 588 千円（表 7 ）と，私たちの 2.5 倍となる.

救命群・死亡群の治療費を動かしてみても, 費用効 果比には大した影響がないことがわかったので, 将来 前立腺がん検診の費用効果分析を行う際には，それほ ぞ治療法について細かく言及する必要はないかもしれ ない.

スクリーニング検査の感度・特異度については, 費 用効果比に大きな影響を及ぼすのは特異度であること がわかった. PSA のカットオフ値を決める時にも, 感 度を高くするあまり特異度が低下し, 経済効率が著し く悪化することがないように気をつける必要がある。

このように本ガイドラインを用いることで，がん検 診において費用効果比に影響を及ぼす因子が容易に理 解でき, 検診を実施する際の要点を把握することがで きた．今後，より精度の高いスクリーニング検査法や より有効な治療法が出現してきても, 同様な試算に
表 7 各種条件下での前立腺がん検診の費用効果比 (千円)

\begin{tabular}{|c|c|c|c|c|}
\hline \multirow{2}{*}{ 年齢 } & \multicolumn{2}{|c|}{ 施 行 } & \multicolumn{2}{|c|}{ 精密検査受診率 } \\
\hline & 1990年 & 2015年 & $88.2 \%{ }^{5)}$ & $44.8 \%{ }^{24)}$ \\
\hline $55-59$ & 2,649 & 1,439 & 236 & 588 \\
\hline $60-69$ & 680 & 176 & -41 & 135 \\
\hline 70-79 & -103 & -342 & -420 & -304 \\
\hline
\end{tabular}

よって，それらを導入するメリットを事前に確認する こともできよう。

\section{結語}

1）前立腺がん集団検診の費用効果比は, 老人保健事 業として我が国ですでに行われている各種がん検診の それと比較して, 非常に良好であった。

2）感度分析の結果, 1990年における有病率で計算し ても, 前立腺がん検診の費用効果比は乳がん検診・女 子の肺がん検診のそれよりも良好であり，前立腺がん が現在最も増加しているがんであることを考えれば, 今後ますます費用効果比は良くなると考元れれた。

3）同じく感度分析によれば, 精密検査受診率・スク リーニング検査の特異度が費用効果比に及ぼす影響は きわめて大きく, 経済効率の観点からも, 前立腺がん 検診を実施する上で最も考慮を払わねばならない要因 であることがわかった。

本研究に関して, 多大なるご助言をいただいた東北大学 公衆衛生学教室助教授辻 一郎先生に深謝する. 本研究の 一部は, 厚生省がん研究助成金久道班 (6-20), 渡邊班 (6-16), (8-9), 深尾班 (8-10) の援助によって行われた.

\section{文 献}

1）渡辺 泱：癌の第二次予防. Oncologia, 12, 5468,1985 .

2）中尾昌宏，渡辺 泱：前立腺疾患の国家社会的損 失と集団検診の経済的効果. 泌尿紀要, 33, 15421546, 1987. 
3）久道 茂，鎌江伊三夫：保健事業における社会経 済的評価法の標準ガイドライン. 厚生省がん研究 助成金久道班 $(6-20)$ 資料。

4) 中川修一, 斎藤雅人, 渡辺 真, 井上 亘, 野本剛 史, 中村晃和, 北村浩二, 渡辺 決：腎·前立腺集 団検診における画像診断. 日本がん検診·診断学会 誌，3，38-43， 1995.

5）中川修一, 渡辺 泱, 渡辺 真, 野本剛史, 中村晃 和, 杉本浩造, 斎藤雅人, 小島宗門, 北村浩二 : 前 立腺特異抗原 (PSA) 濾紙法による前立腺がん検診 の試行．日泌尿会誌，88，399-405，1997.

6）前立腺検診協議会，財団法人前立腺研究財団編： 前立腺集団検診集計。人間ドック検診における前 立腺検查調查報告-1993年度一付前立腺集団検診 集計一-1993年度一, p35-45，東京，1995。

7) 渡辺 決, 中川修一, 斎藤雅人, 渡辺 真: 癌検診 の最前線一前立腺癌一. 癌治療・今日と明日, 17 , 27-30, 1995.

8）渡邊 決：厚生省がん研究助成金「前立腺がんの 集団検診の妥当性に関する研究」班. (6-16) 平成 $6 \cdot 7$ 年度研究成果報告書, 1996 .

9）厚生省保険局医療課，厚生省老人保健福祉局老人 保健課編: 社会保険·老人保健診療報酬. 医科点数 表の解釈 (平成 8 年 4 月版). 第27版, 社会保険研究 所, 東京, 1996.

10）渡辺 泱：我が国における前立腺集団検診の現 況. 日本医事新報, 3600, 27-34, 1993.

11）厚生省大臣官房統計情報部編: 平成 6 年簡易生命 表 (男)。平成 6 年簡易生命表, p14-15, 財団法人 厚生統計協会，東京，1995。

12）杉本浩造, 中川修一, 三神一哉, 野本剛史, 浦野俊 一, 中村晃和, 中西弘之, 渡辺 真, 斎藤雅人, 渡 辺 泱：前立腺癌246例の臨床的検討. 日泌尿会 誌，(投稿中)

13）渡辺 泱, 中川修一, 大江 宏, 斎藤雅人: 病期病態からみた腫瘍の治療対策一泌尿器科腫瘍。医 学と薬学, 23, 671-679, 1990.

14）渡辺 泱, 中川修一, 小島宗門: 器官別早期癌一概
念・診断法・治療法の選択と治療成績一膀胱, 前立 腺癌。日本臨床，54，1405-1409，1996.

15）浦野俊一, 中川修一, 杉本浩造, 三神一哉, 渡辺 泱：ホルモン療法抵抗性前立腺癌に対するCisplatin, Ifosfamide 併用化学療法の検討. 西日泌 尿, 57, 31-34, 1995.

16）今井強一, 鈴木孝憲, 熊坂文成, 黒沢 功, 栗原 潤, 町田昌巳, 牧野武雄, 喜連秀夫, 佐藤 仁, 山 中英寿：前立腺集団検診における受診適齢に関す る検討. 日泌尿会誌，87，1191-1196，1996.

17）松永 弦, 辻 一郎, 佐藤信二, 深尾 彰, 久道 茂, 矢嶋 聰: がん検診の Cost-effectiveness Analysis. Oncol. Chem., 11, 157-160, 1995.

18）久道 茂: 厚生省がん研究助成金による「各種が ん検診の共通問題に関する研究」班。(6-20)平成 7 年度研究報告書, 1996 .

19）久道 茂：胃集検の費用効果分析. 胃集団検診の 実際, p145，金原出版，東京，1978.

20）飯沼 武, 舘野之男 : 癌集団検診の評価のための 数学モデルの 1 試案. 癌の臨床, $36,2427-2433$, 1990.

21）がんの統計編集委員会編: 悪性新生物罹患数, 粗 罹患率および年齢階級別罹患率 (平成 2 年, 全国). がんの統計’95, p40-41, 財団法人がん研究振興財 団, 東京, 1995 .

22）花井 彩, 小榬誠樹, 藤本伊三郎：1990年における 日本のがん有病者数. 癌の臨床, 38, 419-427, 1992.

23）津熊秀明, 北川貴子, 花井 彩, 藤本伊三郎, 黒石 哲生, 富永祐民：日本のがん罹患の将来の予測. が ん・統計白書一罹患/死亡/予後-1993, 第 1 版, p153-170, 篠原出版, 東京, 1993.

24) Imai, K., Ichinose, Y., Kubota, Y., Yamanaka, H. and Sato, J.: Diagnostic significance of prostate specific antigen and the development of mass screening system for prostate cancer. J. Urol., 154, 1085-1089, 1995. （1996年10月7日受付，1997年5月22日受理） 